УДК 003.3:930.85 (477)

DOI: 10.37026/2520-6427-2020-101-1-59-62
Неля МАНДРИК,

кандидат філологічних наук, доцент кафедри стилістики та культури української мови

Рівненського держсавного гуманітарного університету

\title{
ПИСЕМНІСТЬ ЯК ЗАСІБ ПРОНИКНЕННЯ В ІСТОРІЮ УКРАЇНСТВА
}

У статті розвиток слов'янства розглянуто в єдності стадійно закономірного та історично конкретного. Досліджено багатоаспектне бачення соціокультурного становлення наших предків через їх культурний поступ, пов'язаний із формуванням власної слов'янської писемності. Простежено етапи розвитку писемності як надзвичайно захоплююче завдання, адже історія письма як науки є однією із найделікатніших складових історії культури загалом.

Ключові слова: писемність, алфавіт, слов'яни, плем'я, українство, концепція, інтерпретація, ієрогліф, етнос.

В статье развитие славянства рассмотрено в единстве стадийно закономерного и исторически конкретного. Исследовано многоаспектное видение сочиокультурного становления наших предков на основе их культурного прогресса, связанного с формированием собственной славянской письменности. Прослежено этапь развития письменности как чрезвычайно увлекательная задача, ведь история письма как науки является одной из самьх деликатных составляюших истории культуры в иелом.

Ключевые слова: письменность, алфавит, славяне, племя, украинство, концепџия, интерпретаичия, иероглиф, этнос.

The study of the cultural heritage of past centuries is a key issue of our time. Therefore, the development of the Slavs of Ukraine the author considers in the unity stage natural and historically-specific, especially processes that occurred among other groups of the Slavs. To substantial, comprehensive vision of socio-cultural development of our ancestors, you must explore and actually their cultural progress associated with the formation of its own Slavic alphabet.

The reader can be a contemporary one who writes, but he can live thousands of years after him. And only the writing were given the opportunity to transfer works of human thought and history and to preserve them for centuries. The emergence and development of letters connected with the history of the people, who is the Creator and carrier of a particular language.

To trace the stages of development of writing is a task extremely fascinating. Because the history of writing as a science is one of the most delicate parts of the history of culture.
The letter can be viewed not only in connection with the history of the speakers of a certain language, but also in many other plans. Among all possible is focusing on graphic images, through which is perceived the text is written.

With the opening of the letter people received the opportunity to transfer and consolidate their thoughts. In addition to the sound humanity has been enriched and written language, which is now letters of the alphabet.

Key words: writing, the alphabet, the Slavs, the tribe, the Ukrainians, the concept, interpretation, character ethnicity.

Постановка проблеми. Далеко не всім дослідникам щастить піднятися на рівень теоретичного пізнання, особливо в тих сферах, де часто-густо бракує необхідних джерел, а ідеологічні кліше сковували (а подекуди й досі сковують) творчу думку. Це насамперед стосується проблем соціокультурного розвитку українства у переддержавний та ранньодержавний періоди.

Аналіз наукових досліджень і публікацій. Інтерес до проблематики писемності та історії українства знаходимо в працях багатьох видатних учених, серед яких М. Брайчевський [1], М. Грушевський [2; 3], В. Передрієнко [4], Г. Півторак [5] та ін. Їх поєднує комплексний підхід до вивчення тих чи інших аспектів історії розвитку письма зокрема та українства загалом.

Спільними зусиллями вчених із різних галузей науки про людину і суспільство зроблено достатньо i водночас небагато. Достатньо, бо наявні чимало спроб окреслити загальну картину еволюції письма й українства, а небагато, бо дана проблема - то неосяжне «море», що потребує все нових і нових досліджень. I якими б серйозними не були здобутки, їх вага, порівняно 3 невідомим, на жаль, буде незначною. Таким чином, необхідно випробувати всі шляхи до пізнання світу українців.

Мета статті - простежити генезис письма та його роль у розкритті історії давніх українців.

Виклад основного матеріалу. Перші знаки, що вживалися для писання, 3'явилися понад 100 тисяч років тому! При цьому період існування писемності близько 6-ти тисяч років, а базові місця виникнення письма - це Африка (як південна, так і північна), Сгипет, Близький Схід (Месопотамія), Китай.

Існує кілька гіпотез щодо виникнення писемності. За першою письмо виникло в одному місці (але при цьому називаються різні місця), за другою - одночасно в різних місцях. Проте наука дедалі більше схиляється до існування одного центру і найчастіше при цьому називають Шумер [2]. 
Крім того, впродовж останнього часу проводиться чимало досліджень, що стосуються письма палеоліту, тобто кам'яного віку. Таким чином, існування шумерської культури припадає на VI-IV тисячоліття до н. е., а кам'яний вік - на значно раніший період 30-100 тисяч років! Отже, значна кількість культурних феноменів, зокрема й письмо, беруть свій початок ще в кам'яному віці. Свідченням цьому є найдавніші в Україні археологічні пам'ятки - знаменита Мізинська стоянка на півночі та Кам'яна Могила на півдні, де збереглися перші писемні знаки. Тобто, вже кілька десятків тисяч років тому людина намагалася закарбувати на твердих матеріалах (камені, кістці), різноманітні календарні позначки, сакральні знаки, а як наслідок - можна стверджувати, що перші прояви мистецтва письма сягають кам'яного віку, а це кілька десятків, а за іншими дослідженнями, навіть понад сотня тисяч років тому! [1].

До речі, трипільська писемність з'явилася за кілька тисячоліть до виникнення алфавіту. Трипільські ієрогліфи існували вже у V-IV тисячолітті до н. е. Представники цієї хліборобської цивілізації користувалися ієрогліфами, за допомогою яких фіксували сакральну інформацію, адже більшість трипільських знаків - це ієрогліфи на позначення божеств, астрономічні знаки, наприклад, трипільський зодіак. Тож упевнено можемо казати, що не лише Сгипет чи Шумер, а й Трипілля було одним із базових центрів виникнення письма.

Сучасна наука класифікує кілька типів письма. Периий тип - піктографічне (малюнкове) письмо, коли зміст повідомлення відображається у вигляді малюнка або послідовності малюнків (наприклад, якщо в давнину малювали бика, стрілу і стрільця, то це означало, що мисливець убив стрілою бика); при цьому піктограми можна читати будь-якою мовою. Другий тип - ієрогліфічне письмо, де кожен малюнок відображає певне слово конкретною мовою, при цьому ієрогліфи базуються на омонімах (наприклад, давні єгиптяни замість того, щоб малювати бога землі Геба, зображали качку, яка по-єгипетськи також називалася «геб», тобто малювати простішу фігуру, але звучала вона так само, як і складна). Tретій тиn складове письмо, де один знак означає цілий склад. Четвертий тип - алфавітне письмо. Нещодавно науковці віднайшли ще один тип письма, $\boldsymbol{n}$ 'ятий, який з'явився близько 10 тисяч років тому (а можливо, й раніше, тобто в кам'яному віці), -предметне письмо, що існувало в багатьох народів - і в скіфів, і в слов'ян. Ще Геродот описує: коли перси захотіли завоювати скіфів, то ті надіслали персам стрілу, жабу та мишу. Це означало: коли ви не втечете, як миші чи жаби, то ми вас уб'ємо цими стрілами. В Україні предметним письмом користувалися і в XX століттіскажімо, якщо хлопець сватався до дівчини, але та відмовляла, то давала парубкові гарбуза.

С кілька систем писемності, які представлені сьогодні: ієрогліфічна система, що застосовується в Китаї, Японії, Кореї; складове письмо (деванагаpi, або санскрит), поширене в Індії, Таїланді; звуко-буквене письмо, яким користуються у Свропі та США. Аналізуючи етапи розвитку письма, варто виокремити письмо: предметне, піктографічне (малюнкове), деографічне (передача змісту за допомогою деограми - ієрогліфа), складове (силабічне) та фонографічне (звукове) - найвищий етап у становленні і розвитку письма.

Перші системи буквеного письма створювалися на основі 24-х давньоєгипетських алфавітних знаків, які позначали початкові приголосні односкладових слів. Тобто, найдавніші алфавіти складалися лише 3 приголосних, поряд 3 якими передбачалися голосні. Принцип буквеного письма був закладений у єгипетському ієрогліфічному письмі, яке було перенесене згодом до Палестини (Ханаан), а після цього - у фінікійський Біблос (Губла). Та, на думку деяких науковців, цілком можливо, що давні греки наприкінці IX ст. до н. е. запозичили буквене письмо в жителів міста Губла в Лівані, з якими торгували. Від греків його перейняли етруски та римляни в Італії. Поширення християнства сприяло його поширенню на Схід, у Грузію, Вірменію, а також на Північ - у слов'янські землі. Таким чином, починаючи із $\mathrm{X}$ століття, одночасно почали використовуватися кирилиця та глаголиця - слов'янські абетки [4]. Що ж стосується розділових знаків, то до XVIII століття знак оклику називали «крапкою здивування», а крапку з комою ставили замість знака оклику і називали «напівкрапкою». При цьому наука про розділові знаки називалася «вчення про силу крапок». Отже, крапка - найдавніший розділовий знак, зокрема у злитому тексті, в якому не було проміжків між словами, вживали тільки одну крапку вгорі, внизу або посередині рядка.

Розвиток алфавіту, як і будь-якого іншого явища, також має свої етапи. Так, його виникнення пов'язують зі Стародавнім Сгиптом, а становлення - 3 островом Крит, де жили стародавні греки, та Фінікією (країною мореплавців), що знаходилася неподалік від Сирії. Закінчилося становлення алфавіту тим, що 3'явився алфавіт латинський, кириличний. Щодо появи глаголиці (давнішого письма), то стосовно цього також виникає чимало дискусій. Наприклад, одні вчені вважають, що глаголиця походить від найдавніших знаків, які існували на території Північного Причорномор'я та Середземномор'я, тоді як інші пов'язують цю систему 3 давньогрузинським письмом [3].

Алфавіт - це «одяг» для мови. I неправильно буде казати, що мова походить від алфавіту. Це зовсім різні речі. Будь-яку мову можна записати за допомогою алфавіту. Вважається, наприклад, що вірменський алфавіт створив Месроп Маштоц, а кирилицю, згідно з офіційною версією, - святий Кирило, тобто Костянтин-філософ. Щодо корейської абетки, то, як відомо, тривалий час у Кореї користувалися китайськими ієрогліфами, однак у 1444 році тамтешній правитель Седжон запропонував створити нову абетку. Розробляли iї понад два роки. Припускають, що простому народові було легше запам'ятати кілька десятків літер, аніж кілька тисяч ієрогліфів. Незважаючи на те, що в китайській мові близько 100 тисяч ієрогліфів, ієрогліфічне письмо насправді не таке вже й складне, адже поки ми англійською чи українською напишемо одне слово, китаєць швидко намалює знак свого письма. Так, в японській мові слово «мамихлапинатана» вважається наймісткішим на планеті, адже воно означає: «дивитися один на одного з надією, що хто-небудь погодиться зробити те, що бажають обидві сторони, але не хочуть робити». 
Нині ієрогліфи широко використовуються навіть в адресах сайтів.

Без сумніву, винахід письма - це надзвичайно важлива подія, але його (письмо) не варто розглядати ізольовано. Коли письмо з'являлося, то воно було надзвичайно тісно пов'язане зі сферою інформації. 3 одного боку, ми маємо сакральні печерні малюнки (поширені на території від Англії та Франції і аж до Австралії), а з іншого - різні знаки, наприклад, астрономічні (спостерігаючи за сонцем і місяцем, люди закарбовували їхні фази). I це також інформація та її фіксація. А саме письмо виділяється значно пізніше.

Безперечно, навіть сьогодні, на початку XXI століття, і в Африці, і в Південній Америці, і в інших частинах світу наявні чимало кочових племен, які не користуються письмом. Та це не означає, що вони жодним чином не фіксують інформацію. Зокрема, для цього вони використовують різні камінці, палички тощо. Таким чином, людина не може існувати без фіксації інформації. Навіть кочівникам потрібно знати, наприклад, скільки худоби в них є. До речі, неабиякий вплив на виникнення письма мали астрономічні явища, що було пов'язано з господарчими потребами. Люди мусили фіксувати фази місяця, те, коли сходить і заходить сонце. Перший писемний календар виник близько 300 тисяч років тому.

Ми всі усвідомлюємо те, що цілком природним $\epsilon$ процес зникнення одних мов і поява інших. Наприклад, праслов'янська мова дала початок багатьом слов'янським, праіндоєвропейська - близько 500 індоєвропейських. Нині у світі близько 5,5 тис. мов і вони допомагають нам у відтворенні історії, зокрема у нашому випадку - iсторії слов'янства й українства.

У 10 році до н.е. римські джерела вперше згадують про загадкові племена осів (Osovie), які на півночі від Середнього Дунаю підкорив римський консул Марк Візіній. Конкретніші відомості подає про них Тацит (55-120 роки) у своїй «Германії». I хоча він зазначав, що оси не є германцями, аж допоки 1920 року німецький історик Ріттерлінг спростував цю хибну версію, довівши, що це могли бути тільки слов'яни, оскільки римляни згодом зверталися до них за допомогою у боротьбі з германськими племенами. Оси жили на схід від германців, які концентрувалися в той час на заході сучасної Словаччини, тому германці й називали їх «остами», тобто «східним народом» або «східняками». У римлян «ости» трансформувалися в «осів», які й потрапили на сторінки історії. Отже, саме 10-й рік до н. е. слід вважати своєрідною датою «народження» української народності, саме тоді вона вийшла на історичну арену. I те, що саме «оси» - це наші прабатьки, підтверджують й інші згадки. Так, про «Карпатських оросів» (Karpathes Oros) згадує Птолемей у своїй «Географії». Сполучення цих двох етнічних назв в одну є надзвичайно промовистим і свідчить про те, що це вже $\epsilon$ не лише загальна для цілого етносу назва, а конкретна одного $з$ його найбільших племен, що безпосередньо вказує на «карпів» як на давньоруське плем'я. Усі подальші трансформації цієї назви переконують нас, що нею сучасники називали племена, які згодом почали називатися хорватами (карпи - Карпати - горвати - хорвати). Відомо, що саме карпи, а не фракійці витіснили римлян із Дакії, і вражений їх військовим талантом імператор Галерій у 312 році оселив частину цих карпів для захисту германських племен у Паннонії, а інших осів - уздовж лівого берега Дунаю. У V ст. на території Угорщини згадується народ «Rhos», таким чином, назва «оси» поступово трансформується: оси - ороси - роси - русини - руси. Коли 890 року сюди прийшли угорці, то вони називали місцевих жителів оросами (орошами), і ця назва в них збереглася до наших днів. Окремі випадки вживання етнічної назви «рос», «рус», «русин» спостерігаємо у V, VI та VIII століттях, значно частіше - у IX - X, а панівною вона стала, починаючи із XI століття. До цього часу українців переважно знали ще й під їх старою етнічною назвою - словени.

У середині VI ст., ще перед аварською навалою, історик Йордан згадує «словенів, які живуть від Мурсіанського озера (Болотона) до Дністра». Оскільки присутність українців у VI ст. на Дністрі вже доведена, то завдяки цьому можна стверджувати про проживання українців у той час і біля Болотона. Не варто також ігнорувати і свідчення Пріска Понійського, який у 448 році відвідав столицю гунів, яка називалася Бич (на території Угорщини). Хоча у своєму описі він і не вживає назв «словени» чи «русини», але слова, які він згадує (мед, тризна, жито, квас та інші) $є$ суто українськими, а отже, йдеться саме про українців. Ну і, звичайно, не забуваймо про літописця Нестора, який зазначає: «А Словенскый язык й Рускый один есть...», «А первое быша Словени аще й Поляне звахуся», «Первое быша Словени, а ныне зовомая Русь». Таким чином, українська історіографія просто проігнорувала факт існування нашої найдавнішої етнічної назви - «словени». Саме тому в історії українства від VII ст. до н. е. та ледь не до 882 року існує величезне «провалля».

Протягом XI - XVIII століть абсолютно панівною в середовищі українців була назва «руси» або «русини», іiі чергова заміна - на «українців» - відбулася у XIX столітті під тиском принизливих для нашої національної гідності обставин трансформації цієї назви на «малороси». Означена подія «перетворила» нас, українців, на одну з «наймолодших» народностей світу, хоча насправді vb належимо до «найстарших». До речі, ніби передчуваючи щось дуже недобре для українства, історики М. Аркас та М. Грушевський цілком свідомо назвали свої фундаментальні праці «Історія України-Руси». I це одна 3 основних причин того, що в СРСР вони були заборонені.

Крім білих хорватів були й інші племена, що називалися русинами. Одночасно з остаточним закріпленням за білими хорватами цієї назви русинами почали називатися і поляни, волиняни, дуліби, дреговичі, сіверяни та інші руські племена. Ця спільна для Карпатської, Київської і Галицької Русі назва протрималася аж до XIX століття. Саме тоді наші перші інтелектуали в Києві поставили перед собою питання, яке зараз обговорюємо й ми: «Звідки єсть пошла земля Руськая?».

На території Угорщини народилися не тільки наші старі етнічні назви, а й тривалий час, як мінімум до II століття, перебував давньоруський архетип, де формувалися і народжувалися всі давньоруські племена. Чи то за природних умов (архетип зазвичай переміщується у просторі та часі), 
чи то під тиском скіфів, сарматів та фракійців, але протягом V - III століть архетип перемістився спочатку на Пряшівщину, потім - на протилежний бік Карпат, у район Дунайця та Іголомлі, а ще пізніше на Волинь. Археологія цього періоду також засвідчує, що пряшівська культура 3 території Словаччини та Угорщини поширилися на Прикарпаття і поступово трансформувалася в культуру карпатських курганів і так звану пшеворську. Оскільки кераміка прикарпатських городищ має аналоги лише в Україні, гідроніми і топоніми на схід від Вісли є руські, отже, на території усього Прикарпаття жили тільки руські племена.

У наш час археологи зафіксували концентрацію величезної кількості населення в галицькому Стільську, який тоді був більшим за Париж. У $\mathrm{X}$ - XI століттях еволюція слов'янського (і разом iз ним давньоруського) архетипу з регіону Букових гір, Пряшівщини та Іголомлі завершилася тим, що він опинився на території Галичини (Стільсько) та Волині (Червенські міста). Саме тому, вочевидь, навіть у наш час саме Галичина і Волинь (а не Наддніпрянщина, котру традиційна історіографія визнає «серцем України») є найбільш «затятимb» у відстоюванні українства регіонами. I цьому також $є$ історичне пояснення. Причому його не можна примітивно обмежувати перебуванням українських земель у складі різних імперій після занепаду Київської Русі та Галицько-Волинської держави. Якщо завершальним етапом еволюції індоєвропейського архетипу було утворення слов'янства, то кінцевим результатом існування самого слов'янського архетипу було виникнення українства, генетичне ядро якого, поза всяким сумнівом, становлять білі хорвати (Велика Хорватія) і волиняни (Червенські міста). Іншими словами, саме український етнос $є$ стовбурним етносом як слов'ян, так і індоєвропейців, і лише йому притаманний феномен розвитку одночасно як у східному, так і західному напрямах. Якщо навіть тепер поділ українців на західних і східних заводить учених та політологів у глухий кут, а у європейців ця «своєрідність» уже сприймається як «ненормальність» і викликає неприховане роздратування, то для XIX століття такий стан речей був узагалі незрозумілим.

Археологи відзначають дивовижну ідентичність пам'яток матеріальної культури VII - IX століть на всьому величезному просторі від Влтави до Дніпра та від Дунаю до середньої течії Вісли. Як житло тут використовували типові руські напівземлянки з вогнищем у кутку, однаковий ліпний посуд, предмети вжитку та ремесла, тобто все свідчить про те, що ця культура належала одному етносу (поселення Прага, Рипнів, Корчаки, Тетерівка, Зелений Гай, Злотники, Мацькувка, Нова Гута, Бжезно, Беховіце). Як показали дослідження, корені цієї культури сягають пряшівської культури перших століть нашої ери, яка локалізувалася у північно-східній Словаччині, а потім перемістилася на територію Прикарпаття. Отже, висхідною точкою великого розселення давньоруських племен не тільки на схід, а й на захід була територія Словаччини і Прикарпаття, де власне і містився в той час давньоруський архетип. Таким чином, карта поширення пряшівсько-корчаківсько-зарубенецької культури $€$ водночас найповнішою кар- тою розселення давньоруських племен протягом VII-IX століть. Тоді ця територія включала на теренах Польщі не лише Лемківщину, Надсяння, Холмщину та Підляшшя, а всю східну частину сучаного Мазовша, Малу Польщу і Сілезію. Отже, $є$ підстави стверджувати не тільки про угорську Русь, а й про Русь польську, чеську та румунську, хоча остання аж до XIX століття, як до речі й Словаччина, також входила до поняття «угорська Русь». Найбільшим давньоруським плем'ям, яке займало ледь не всю цю землю на території сучасних Чехії, Словаччини, Польщі, Угорщини і частково Румунії, були білі хорвати. I недарма всі науковці концентрують свою увагу саме на них.

Висновок. Сучасні нації сформувалися у XVIII - XX століттях і не зводять поняття «українство» до поняття «український народ». Український народ $є$ лише завершальним етапом розвитку українства. Однак генетичне дерево не слід сприймати лише як «стовбур із верхівкою», оскільки тоді загальна картина буде не зовсім повною і далекою від істини. В усій своїй красі це генетичне дерево постане тільки тоді, коли зможемо оцінити його найбільш повний і загальний вигляд, а не лише окремі частини. Однак до західних українців належать не лише вони, а й дуліби, бужани і частково ті волиняни, які в X столітті мали свій центр на території Червенських міст та заселяли тоді всю територію від Вісли до Волині. Таким чином, генетичне ядро українства становлять саме волиняни, оскільки з усіх племен, котрі склали основу українського народу, лише вони розвивалися, одночасно на захід і на схід, тобто мають найбільший генетичний потенціал й усі ознаки етнічного стовбура нашої нації.

\section{СПИСОК ВИКОРИСТАНОЇ ЛІТЕРАТУРИ}

1. Брайчевський М. Походження слов'янської писемності / М. Брайчевський. - К. : Видавничий дім «Києво-Могилянська академія», 2002. - 154 с.

2. Грушевський М. Культурно-національний рух в Україні / М. Грушевський. - К., 1919 - С. 43.

3. Грушевський М. Історія України-Руси : в 11 т. / М. Грушевський ; редкол. : П. С. Сохань (голова) та ін.К. : Наук. думка, 1991. - Т. 1. - С. 188-193.

4. Передрієнко В. А. Приватні листи XVIII ст. / В. А. Передрієнко. - К., 1919 - С. 7.

5. Півторак Г. Як розмовляти в стародавньому Києві / Г. Півторак // Вісник міжнародної асоціації українців. - К., 1990. - С. 39.

6. Свєшников I. Звенигородські грамоти на бересті / І. Свєшников // Дзвін. - 1990. - № 6. - С. 128.

7. Соболевський А. И. Кириловская часть Реймского евангелия / А. И. Соболевський // Русский филологический вестник, - Варшава, 1887. - T. XVIII. C. $144-150$.

8. Улуханов И. С. О языке Древней Руси / И. С. Улуханов. - Москва, 1972. - С. 11-12.

9. Щапов Я. Н. Государство и церковь Древней Руси X - XIII вв. / Я. Н. Щапов. - Москва, 1989. C. 139 .

10. Regel W. Analekta buzantine zusika. Санкт-Петербург, 1891. - С. 44-51.

Дата надходження до редакиї: 04.12.2019 р. 